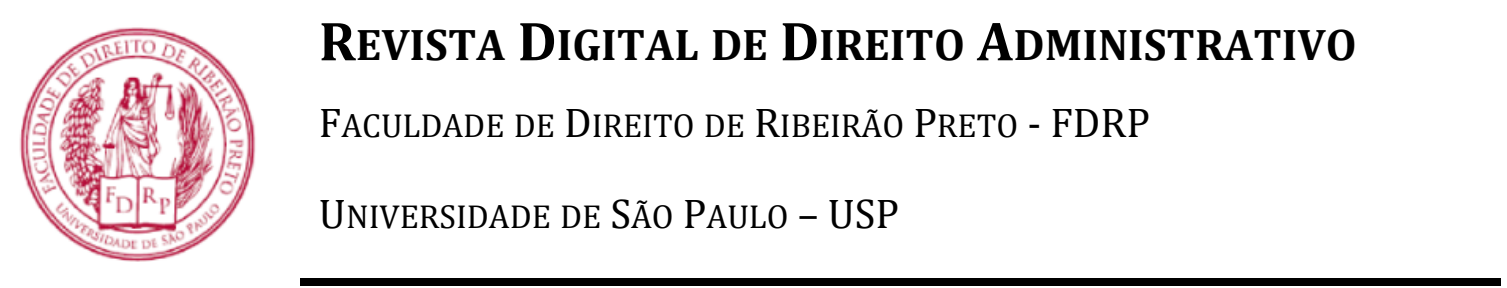

Seção: Artigos Científicos

\title{
A delimitação do erro grosseiro na jurisprudência do Tribunal de Contas da União
}

\author{
The delimitation of "gross mistake" inside the jurisprudence of the General Accounting Office
}

Ingrid Caroline Santos Andrade, Aline Sueli de Salles Santos

\begin{abstract}
Resumo: A presente pesquisa trata da delimitação do erro grosseiro dentro da jurisprudência do Tribunal de Contas da União. A Lei 13.655/2018 inclui na Lei de Introdução às Normas do Direito Brasileiro (Decreto-Lei 4.657/1942) dispositivos acerca da eficiência na criação e aplicação do direito público e disposições sobre segurança jurídica, entre as suas alterações, inclui-se o artigo 28 que trouxe novas definições relativas à responsabilização do agente público. Em razão de ser considerada norma de sobredireito, a LINDB traz critérios interpretativos aplicáveis às esferas administrativa, controladora e judicial. Desse modo, o objetivo do presente trabalho é traçar o entendimento do Tribunal de Contas da União acerca do critério do erro grosseiro inserido pelo artigo 28, no exercício de sua atividade de controle externo da administração pública. Assim, através de método indutivo com análise da doutrina e jurisprudência do Tribunal de contas, esta pesquisa busca abordar os aspectos relativos ao controle e apuração da responsabilidade perante esse tribunal, as recentes mudanças na LINDB com enfoque no artigo 28 e a aplicação dessas alterações na jurisprudência do Tribunal de Contas da União.
\end{abstract}

Palavras-chave: Tribunal de Contas da União, Erro Grosseiro, LINDB.

Abstract: This present research is a study about the delimitation of "gross mistake" inside the jurisprudence of the General Accounting Office. Law 13.355/2018 includes in the Law of Introduction to the Norms of Brazilian Law (Decree-Law n. 4.657/1942) legal provisions about the efficiency at the creation and application of public law and provisions about legal safety, as the art. 28, which brought new definitions related to the accountability of the public agent. Considered a norm of overright, the LINDB brings interpretative criteria applicable to the administrative spheres, comptroller and judicial. Thereby, the main goal of this research is to trace the understanding of the General Accounting Office about the criteria of "gross mistake" inserted by the art. 28, at the exercise of its activity, in the exercise of its activity of external control of public administration. Thus, through the inductive method with doctrine and General Accounting Office's jurisprudence analysis, this research aims to approach the aspects related to control and investigation of responsibility towards this court, the recent changes to the LINDB with focus on the art. 28 and the application of these modifications at the jurisprudence of the General Accounting Office.

Keywords: General Accounting Office, Gross mistake, LINDB.

Disponível no URL: www.revistas.usp.br/rdda

DOI: http://dx.doi.org/10.11606/issn.2319-0558.v7n2p310-342

Este conteúdo está protegido pela lei de direitos autorais. É permitida a reprodução, desde que indicada a fonte como "Conteúdo da Revista Digital de Direito Administrativo". A RDDA constitui periódico científico da FDRP/USP, cuja função é divulgar gratuitamente pesquisa na área de direito administrativo. Editor responsável: Professor Associado Thiago Marrara. 


\section{A DELIMITAÇÃO DO ERRO GROSSEIRO NA JURISPRUDÊNCIA DO TRIBU- NAL DE CONTAS DA UNIÃO}

Ingrid Caroline Santos ANDRADE, ${ }^{*}$ Aline Sueli de Salles SANTOS**

Sumário: 1. Introdução; 2. O controle da administração pública e a responsabilização de agentes públicos com enfoque no TCU; 2.1. O Controle da administração pública; 2.2. Tribunal de Contas da União e o controle externo; 2.2.1 O Processo de Contas; 2.3. A Responsabilidade perante o Tribunal de Contas; 3. A Lei 13.655/2018 na Lei de Introdução às Normas do Direito Brasileiro (LINDB); 3.1. 0 Projeto de Lei 7.448/2017; 3.2. O veto parcial do artigo 28 e o Decreto 9.830/2019; 4 . O erro grosseiro em face da jurisprudência do Tribunal de Contas da União; 4.1. A análise jurisprudencial; 4.1.1. O erro grosseiro como culpa grave; 4.1.2. O erro grosseiro e a opinião técnica; 4.2. 0 erro grosseiro e a responsabilidade financeira; 5. Conclusões; 6. Referências bibliográficas

\section{Introdução}

A administração pública em sentido objetivo consiste em atividade estatal que defende o interesse público, em razão disso possui regime jurídico diferenciado, que lhe concede prerrogativas de supremacia sobre o particular, mas, também, possui sua atuação limitada pelo ordenamento jurídico de forma a proteger o cidadão de qualquer forma de arbitrariedade durante a sua atividade.

De forma a garantir que a atuação da administração atenda à finalidade precípua da satisfação do interesse público, existem sistemas de controle cujos objetivos são garantir uma atuação dentro dos ditames legais e, como tal, examinar a responsabilidade em casos de inobservância dos deveres impostos pelo regime jurídico administrativo.

Dessa forma, o conceito de Estado de direito é indissociável da ideia de controle e responsabilização em casos de irregularidades. 0 Tribunal de Contas da União (TCU) é órgão que desempenha o controle administrativo externo da Administração Pública, incluído no rol das suas competências está a função sancionadora com a aplicação de penalidades a agentes públicos após o devido processo.

Recentemente, a Lei no 13.655, de 25 de abril de 2018, incluiu na Lei de Introdução às Normas do Direito Brasileiro (LINDB) disposições com o objetivo de majorar os

\footnotetext{
${ }^{*}$ Bacharel em Direito pela Universidade Federal do Tocantins. Pós-graduanda em Direito e Prática Previdenciária pela Faculdade Legale.

** Doutora em Direito pela Universidade de Brasília. Professora de Direito Administrativo da Universidade Federal do Tocantins. Ex-conselheira da Comissão de Anistia do Ministério da Justiça do Brasil.
} 
níveis de segurança jurídica e eficiência na criação e aplicação do direito público. A LINDB trata de normas e princípios aplicáveis a todos os ramos jurídicos, definindo aspectos sobre a aplicabilidade, interpretação, integração e aplicação das normas jurídicas. (FARIAS; ROSENVALD; NETTO, 2018, p. 163). Desse modo, as recentes alterações são aplicáveis a esfera controladora.

Em justificativa, a Lei 13.655/2018 busca fornecer novas balizas interpretativas, processuais e de controle a serem seguidos pela administração pública a fim de se melhorar a qualidade da atividade decisória, elevando-se a segurança jurídica. Um dos dispositivos incluídos foi o artigo 28 que prevê a responsabilidade pessoal do agente público por suas decisões ou opiniões técnicas somente em casos de dolo ou erro grosseiro.

Porém, o termo "erro grosseiro" apresenta-se como conceito jurídico indeterminado, de enunciação abstrata, dependendo a sua interpretação do critério do julgador. E, em veto presidencial, excluíram-se os parâmetros para a configuração do erro grosseiro.

Diante da relevância do controle para um Estado democrático de Direito e a segurança jurídica exigível para aplicação de normas de responsabilização dos agentes públicos, mostra-se relevante traçar a conceituação de erro grosseiro para o Tribunal de Contas da União após as alterações da LINDB. Dessa forma, o presente artigo se propõe a abordar o controle exercido pelo TCU e apuração da responsabilidade perante esse tribunal, as recentes mudanças na LINDB e a aplicação dessas alterações na jurisprudência do Tribunal de Contas da União. Através do método indutivo foi realizada uma análise da doutrina e jurisprudência para abordar os aspectos acima elencados.

\section{0 Controle da administração pública e a responsabilização de agen- tes públicos com enfoque no TCU}

Cabe ao item inicial do presente trabalho apresentar noções acerca do Controle da administração pública. Pretende-se discorrer sobre o controle externo da administração com enfoque no Tribunal de Contas, com a definição de aspectos gerais sobre o processo de contas e a responsabilidade do agente público em âmbito constitucional e na esfera controladora da Corte de Contas.

\subsection{O Controle da administração pública}

A administração pública em sentido estrito pode ser compreendida em aspectos subjetivos e objetivos. 0 primeiro compreende as pessoas, órgãos e agentes que exercem a função administrativa, enquanto o segundo é a própria atividade administrativa em si (DI PIETRO, 2019, p. 74). 
A função administrativa é atividade subordinada a lei que tem como finalidade a defesa e a gestão dos interesses públicos, concretizada por meio da prestação de serviços públicos. Em razão disso, a administração pública direta e indireta sujeitase ao duplo controle das suas atividades, exercido pelo poder Legislativo e Judiciário, e também pela administração sobre os próprios atos. Desse modo, o controle busca assegurar a correspondência entre as atividades da administração e as normas ou princípios aos quais se sujeita.

Sobre o controle da administração pública, Maria Sylvia Zanella Di Pietro (2019, p. 921) opina que:

(...) pode-se definir o controle da administração Pública como o poder de fiscalização e correção que sobre ela exercem os órgãos dos Poderes Judiciário, Legislativo e Executivo, com o objetivo de garantir a conformidade de sua atuação com os princípios que lhe são impostos pelo ordenamento jurídico.

Para Meirelles (2016, p. 795), o controle pode ser entendido como "a faculdade de vigilância, orientação e correção que um Poder, órgão ou autoridade exerce sobre a conduta funcional de outro". Simplificadamente, o controle pode ser definido como uma série de mecanismos jurídicos e administrativos dos quais se exerce a fiscalização e revisão da atividade administrativa.

Com previsão expressa no Decreto Lei no 200 de 1967, os mecanismos de controle tem sua natureza jurídica definida como princípio fundamental da administração pública (MAZZA, 2018, n.p.).

O controle pode ser classificado conforme diversos critérios, para o objetivo do presente trabalho, interessa saber a classificação que divide o controle em interno e externo. A doutrina diverge quanto a nomenclatura desse critério, para Meirelles (2016, p. 796) é quanto a posição do órgão controlador, para Marinela (2010, p. 924), é referente a extensão do controle, enquanto, para Justen Filho (2009, p. 985), é consoante à relação entre o titular e o destinatário do controle.

O controle interno é aquele exercido por um Poder sobre seus próprios órgãos e agentes, o agente controlador integra a própria administração objeto do controle (LIMA, 2018, p. 43), enquanto o controle externo "é o que se realiza por um Poder ou órgão constitucional independente funcionalmente sobre a atividade administrativa de outro Poder estranho à Administração responsável pelo ato controlado" (MEIRELLES, 2016, p. 798).

A Constituição Federal (CF) brasileira de 1988 atribui em seu artigo 70 o controle externo da administração pública ao Poder Legislativo, e nos moldes do artigo 71, esse controle é realizado com o auxílio do Tribunal de Contas da União. Logo, o controle externo pode ser entendido de maneira ampla, quando exercido por qualquer 
ente alheio ao ente controlado, e também pode ser entendido de maneira restrita, que é o controle exercido pelo Poder Legislativo e pelo Tribunal de Contas conforme a previsão constitucional.

\subsection{Tribunal de contas da União e o controle externo}

O Tribunal de Contas da União auxilia o Congresso Nacional no controle externo da administração pública, com sua competência definida na Constituição, o órgão federal é responsável pela fiscalização financeira, contábil, orçamentária, operacional e patrimonial da administração pública quanto à legalidade, legitimidade e economicidade de forma a garantir a probidade administrativa e a eficiência na gestão dos recursos públicos.

O Tribunal de Contas é órgão técnico, autônomo e independente, e suas decisões possuem natureza administrativa, sendo o foro paralelo ao parlamento para julgamento das despesas públicas, a Corte de Contas possui uma interdependência funcional com o Congresso, não guardando nenhuma relação de subordinação com o mesmo.

Para a consecução das atribuições funcionais do Tribunal há distintos processos de controle externo com as suas especificidades, esses podem ser categorizado em três grupos: o processo de contas, o processo de fiscalização e o processo de pessoal. Para o presente trabalho, é mister entender o processo de contas.

\subsubsection{O Processo de Contas}

Dentre as diversas competências que a Constituição da República atribui ao Tribunal de Contas, inclui-se a fiscalização das contas dos administradores e demais responsáveis por dinheiros, bem como a aplicação de sanções em casos de ilegalidade de despesa ou irregularidade de contas. 0 controle daquela corte alcança qualquer ente ou setor privado que realize o manuseio de recurso federal.

A Constituição, em seu artigo 71, inciso II, faz referência a dois tipos de contas: as contas ordinárias que compreendem as contas dos administradores que exercem atividade de gestão de recursos públicos federais e as contas extraordinárias, que abrangem as contas daqueles que derem causa a perda, extravio ou outra irregularidade cuja consequência seja o prejuízo ao erário.

Os processos de contas consistem em instrumentos de avaliação de gestão e de responsabilização de pessoas. São os atos administrativos de gestão financeira, orçamentária, contábil, patrimonial e, eventualmente, operacional que se submetem ao exame do Tribunal (LIMA, 2018, p. 290).

0 processo de Contas ao avaliar os atos administrativos, verifica a regularidade do ato com base nos padrões previstos no artigo 70 da Constituição Federal, são eles os parâmetros de legalidade, legitimidade e economicidade. 
Quanto ao parâmetro da legalidade, Lima (2018, p. 71) esclarece que a "legalidade, no caput do art. 70 da CF, refere-se ao controle da obediência das normas legais pelo responsável fiscalizado. 0 controle da legalidade verifica a obediência às formalidades e aos preceitos previstos no ordenamento jurídico positivo".

Enquanto isso, o parâmetro da legitimidade não encontra limite na adesão de regulamentos e cumprimento da lei, os atos podem ser classificados como legítimos ao serem praticados visando o interesse público ou a melhoria da gestão.

Para Mileski (2003, apud LIMA, 2018, p. 71):

Legitimidade seria então estar conforme à lei e ao Direito. Contudo, deixa de encerrar apenas uma conformação de natureza legislativa, indo mais além, na medida em que se estrutura em fundamentos de moralidade, identificando-se com os valores, princípios e fins que regem a ação administrativa, na consecução dos objetivos estatais - o interesse público.

Quanto à análise da legitimidade, Lima (2018, p. 72) aponta a necessidade da "formulação de um juízo de valor, uma avaliação das circunstâncias em que o ato foi praticado, uma ponderação da prioridade relativa entre a despesa efetuada e as outras necessidades da comunidade".

Em relação ao parâmetro da economicidade, esse princípio analisa se o ato administrativo utilizou os recursos com prudência e razoabilidade, deve ser entendida como a minimização dos custos dos recursos utilizados na consecução de uma atividade, sem comprometimento dos padrões de qualidade. Trata-se da gestão adequada dos recursos colocados à sua disposição.

Ao final do processo de contas, as contas dos responsáveis são julgadas regulares, regulares com ressalvas ou irregulares. A Lei Orgânica do Tribunal de Contas da União (LOTCU), Lei no 8.443, de 16 de Julho de 1992, em seu art. 16 define as contas regulares "quando expressarem, de forma clara e objetiva, a exatidão dos demonstrativos contábeis, a legalidade, a legitimidade e a economicidade dos atos de gestão do responsável".

Ao passo que as contas regulares com ressalvas, assim são classificadas quando "evidenciarem impropriedade ou qualquer outra falta de natureza formal de que não resulte dano ao Erário” (LOTCU, art. 16).

Lima (2018, p. 334) esclarece que:

0 julgamento pela regularidade com ressalvas implica que o Tribunal dará quitação ao responsável e lhe determinará, ou a quem lhe haja sucedido, a adoção de medidas necessárias à correção das impropriedades ou faltas identificadas, de 
modo a prevenir a ocorrência de outras semelhantes. 0 acórdão de julgamento deverá indicar, resumidamente, os motivos que ensejam a ressalva das contas.

(...) Contas apresentadas em desacordo com as normas legais e regulamentares aplicáveis à matéria poderão ser julgadas regulares com ressalva, desde que se comprove, por outros meios, a boa e regular aplicação dos recursos.

A Lei Orgânica do Tribunal define as contas irregulares quando apresentam ocorrências de omissão no dever de prestar contas, dano ao erário decorrente de ato de gestão ilegítimo ao antieconômico, desfalque ou desvio de dinheiros, bens ou valores públicos, práticas de ato de gestão ilegal, ilegítimo, antieconômico ou infração à norma legal ou regulamentar de natureza contábil, financeira, orçamentária, operacional ou patrimonial e, ainda, em casos de reincidência no descumprimento de determinação de que o responsável tenha tido ciência, feita em processo de tomada ou prestação de contas. (LOTCU, art. 16)

É competência da Corte de Contas formular um juízo sobre a gestão dos responsáveis por recursos federais e, ainda, fixar a responsabilidade do agente público em algumas hipóteses de contas julgadas irregulares. Dessa forma, para o presente trabalho, é relevante definir conceitos gerais acerca da responsabilidade, bem como conceitos relativos a responsabilidade apurada perante os Tribunais de Contas.

Vale ressaltar que, enquanto o TCU realiza o julgamento de contas dos administradores e demais responsáveis por dinheiros, bens e valores públicos, além daqueles que gerarem prejuízo ao erário, é competência do Poder Legislativo realizar julgamento político das contas de governo dos chefes do Executivo, com o auxílio técnico do Tribunal de Contas.

Em julgamento realizado em agosto de 2016, o Supremo Tribunal Federal (STF) no Recurso extraordinário (RE 848.826) com repercussão geral, analisou se a competência para julgamento das contas de prefeito municipal era da Câmara de Vereadores ou do Tribunal de Contas. O Relator Min. Roberto Barroso definiu contas de governo e contas de gestão, discutindo que a competência para julgamentos de contas deveria ser atribuído à Casa Legislativa ou ao TCU a depender da natureza da conta.

Assim, contas de governo, que podem ser definidas como contas de desempenho ou resultados, que demonstram o cumprimento de orçamentos, planos e programas de governo, referem-se à atuação do chefe do executivo como agente político. Desse modo, o Tribunal de Contas deveria apresentar um parecer prévio e a casa legislativa possuiria competência para julgar em definitivo, nos termos do art. 71, I, da CF. 
Enquanto as contas de gestão, que trata de contas de ordenação e referem-se a despesas, possibilitam o exame administrativo que compõe a gestão contábil, financeira, orçamentária, operacional e patrimonial do ente público. Portanto, a competência para julgá-las seria do Tribunal de Contas, em definitivo, sem a participação da Casa Legislativa.

No entanto, por maioria de votos, o Plenário decidiu que é exclusivamente da Câmara Municipal a competência para julgar as contas de governo e as contas de gestão dos prefeitos, cabendo ao Tribunal de Contas competente auxiliar o Poder Legislativo municipal, emitindo parecer prévio e opinativo, cujo parecer somente deixará de prevalecer por decisão de $2 / 3$ dos vereadores. Dessa forma, retirando dos Tribunais de Contas a competência para julgar as contas de prefeito que age como ordenador de despesas.

\subsection{A Responsabilidade perante o Tribunal de Contas}

O Estado por meio do ordenamento jurídico impõe uma série de direitos e deveres para a manutenção da ordem social e o descumprimento dessas imposições acarretam em consequências jurídicas. Dessa forma, assim como o ordenamento jurídico tutela algumas das atividades dos indivíduos que se comportam conforme a lei, também traz disposições para aqueles que o contrariam.

A infringência da lei e princípios jurídicos, a violação de um dever jurídico configura um ato ilícito. Se o desrespeito a um dever jurídico gerar dano a alguém, nascerá, então, a responsabilidade de reparar o dano. Segundo Venosa (2009, p. 18), a responsabilidade como gênero pode ser definida como o exame de conduta voluntária violadora de um dever jurídico.

Segundo Sergio Cavalieri Filho (2012, p. 2):

A violação de um dever jurídico configura o ilícito, que, quase sempre, acarreta dano para outrem, gerando um novo dever jurídico, qual seja, o de reparar o dano. Há, assim, um dever jurídico originário, chamado por alguns de primário, cuja violação gera um dever jurídico sucessivo, também chamado de secundário, que é o de indenizar o prejuízo. A título de exemplo, lembramos que todos têm o dever de respeitar a integridade física do ser humano. Tem-se, aí, um dever jurídico originário, correspondente a um direito absoluto. Para aquele que descumprir esse dever surgirá um outro dever jurídico: o da reparação do dano.

Percebe-se que o dever jurídico é originário, enquanto a responsabilidade surge como dever jurídico sucessivo, consequente da violação do primeiro. A responsabilidade pode possuir natureza civil, penal e administrativa, cada uma com suas espe- 
cificidades, a princípio independentes. Entretanto, a prática de um ato ilícito pode configurar, simultaneamente, responsabilidade em mais de uma das esferas.

Na responsabilidade penal, o agente viola uma norma penal, de direito público e lesa o interesse da sociedade. Enquanto isso, a responsabilidade civil é patrimonial e resulta de dano a interesse privado, ficando a cargo do prejudicado a escolha de pleitear a reparação. A responsabilidade civil subdivide-se em objetiva e subjetiva.

Para a doutrina clássica, também chamada de subjetiva, são necessários a presença de nexo causal, conduta comissiva ou omissiva, o resultado de dano e a culpa para sua configuração. A culpa é o principal pressuposto da responsabilidade no plano subjetivo e o ônus de prová-la recai sobre aquele que pleiteia a reparação.

Em contrapartida, a responsabilidade civil objetiva dispensa a culpa. Ainda que exista no caso concreto, sua presença é desnecessária para configuração da responsabilidade. Seu postulado, segundo Gonçalves (2018, p. 513) é "que todo dano é indenizável e deve ser reparado por quem a ele se liga por um nexo de causalidade, independentemente de culpa."

Em determinadas circunstâncias, a culpa será presumida, havendo a inversão do ônus da prova e cabendo ao autor do dano demonstrar a ausência de culpa. Na seara pública, compete ao gestor demonstrar que empregou corretamente os recursos que lhe são confiados.

A Constituição em artigo $37, \S$ 6ำ prevê que pessoas jurídicas de direito público e as de direito privado prestadoras de serviços públicos responderão pelos danos que seus agentes, nessa qualidade, causarem a terceiros, assegurado o direito de regresso contra o responsável nos casos de dolo ou culpa.

Enquanto isso, o Código Civil de 2002 em seu art.43 também define que pessoas jurídicas de direito público interno são civilmente responsáveis por atos dos seus agentes em casos de danos a terceiros, porém, ressalvado direito regressivo contra os causadores do dano em casos de culpa ou dolo.

Dessa forma, percebe-se que a Constituição Federal consagra a responsabilidade objetiva, porém, prevê excludentes da responsabilidade. Da mesma forma, o Código Civil consagra a teoria da responsabilidade objetiva.

Enquanto isso, José dos Santos Carvalho Filho define que o fato gerador da responsabilidade varia conforme a norma jurídica que o contempla. Assim, se o fato gerador da responsabilidade possuir previsão em norma administrativa, dar-se-á a responsabilidade administrativa (2011, p. 500).

No âmbito constitucional, o artigo 37 da CF que trata das disposições gerais sobre a administração pública prevê em seu $\S 4^{\circ}$ a base constitucional da improbidade administrativa, e ainda em seu $\S 6^{0}$ prevê o direito de regresso do Estado contra o 
agente público que, nessa qualidade, causar dano a terceiro, sendo necessário a comprovação do seu dolo ou culpa.

A Lei 8.112, de 11 de dezembro de 1990, que dispõe sobre o regime jurídico dos servidores públicos civis da União, das autarquias e fundações públicas federais, define em seu artigo 121 que o servidor responde administrativamente pelo exercício irregular de suas atribuições. Ainda, em seu artigo 124, define que "a responsabilidade civil-administrativa resulta de ato omissivo ou comissivo praticado no desempenho do cargo ou função". (BRASIL, 1990)

Assim, agentes públicos estão sujeitos ao controle externo quando administram recursos públicos, a responsabilidade também alcança administradores e responsáveis por dinheiro, bens e valores públicos, bem como particulares que derem causa a perda extravio ou outra irregularidade de que resulte prejuízo ao erário público.

A LOTCU define no artigo $1^{\circ}$ a competência do Tribunal de Contas para julgar as contas dos agentes supracitados. Ainda, em seu artigo 1ํ, inciso IX e artigo 56 prevê a aplicação de sanções para administradores e responsáveis.

0 TCU trabalha com o pressuposto de que o ato ilícito é fundamento para reparação do dano. Desse modo, possui uma abordagem também da responsabilidade civil. Dessa forma, realiza uma apuração civil-administrativa. Sua análise é de natureza subjetiva, ou seja, exige-se a presença do elemento culpa em sentido amplo, conforme pacificado na jurisprudência do TCU:

Enunciado: A responsabilidade dos gestores perante o TCU, por ser de natureza subjetiva, pode se originar de conduta comissiva ou omissiva, dolosa ou culposa, cujo resultado seja a violação dos deveres impostos pelo regime de direito público aplicável àqueles que administram recursos da União. (Acórdão 1316/2016-Plenário)

Enunciado: A responsabilidade dos gestores perante o TCU é de natureza subjetiva, podendo se originar de conduta comissiva ou omissiva, dolosa ou culposa (...) aos que causarem prejuízo aos cofres públicos. (Acórdão 6660/2015-Segunda Câmara)

Assim, a responsabilidade administrativa apurada no Tribunal de Contas decorre de prática de irregularidade na gestão de recursos federais por agente sob a jurisdição do tribunal, havendo ou não prejuízo ao Erário, com conduta dolosa ou culposa, cujo resultado seja a violação dos deveres impostos pelo regime de direito público aplicável aqueles que administram recursos do estado ou ainda aos que, sem deter essa condição, causarem prejuízo aos cofres públicos.

Vale ressaltar que a responsabilidade apurada pela Corte de Contas não possui natureza disciplinar. Desse modo, ainda que uma conduta possa ser caracterizada co- 
mo infração em ambas as searas, a responsabilidade administrativo disciplinar do servidor e a responsabilidade a ser apurada pelo TCU não se confundem (FURTADO, 2007 apud TCU, 2013, p. 12).

O dano material não é requisito para todas espécies processuais no Tribunal de Contas. Logo, é possível a prática de atos que não causem dano ao erário, mas que também acarretem em responsabilidade do gestor público. No caso de agentes públicos, o requisito fundamental é que a conduta possa ser enquadrada como ato de gestão administrativa de recursos federais. (TCU, 2013, p. 12). Em casos de particulares, a conduta ilícita para dar margem à responsabilização perante o TCU requer dano a recursos da União, independentemente de ter atuado como agente da administração pública.

Quanto ao trâmite, os processos da Corte de Contas observam o rito definido na LOTCU e no Regimento Interno da Corte (RITCU). 0 processo no TCU é gratuito e sua autuação, tramitação e gestão documental e processual, em regra, são realizados em meio eletrônico.

Conforme artigo 144 do RITCU, são partes no processo o responsável e o interessado. Responsável é aquele que figura no processo em razão de utilização, arrecadação, guarda, gerenciamento ou administração de dinheiro, bens e valores públicos, pelos quais a União responda, ou que, em nome desta, assuma obrigações de natureza pecuniária, ou por ter dado causa a perda, extravio ou irregularidade que resulte em prejuízo ao Erário.

Já o interessado é terceiro que, em qualquer etapa, tenha reconhecido, pelo relator ou pelo Tribunal, razão legítima para ingressar como parte no processo de controle externo (RITCU, art. 144, $§ 2^{\circ}$ ). Nos processos em tramitação no TCU não é obrigatório que a parte esteja representada por advogado. Conforme o art. 145 do RITCU, as partes podem praticar os atos processuais diretamente ou por intermédio de procurador regularmente constituído, ainda que não seja advogado.

Conforme o artigo 156, caput do RITCU, o processo de controle externo desenvolve-se em quatro etapas que são a instrução, o parecer do Ministério Público, o julgamento e os recursos. As contas dos administradores e responsáveis são anualmente submetidas a julgamento do Tribunal, sob forma de tomada ou prestação de

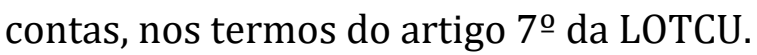

Constatada omissão, não comprovação da aplicação dos recursos ou qualquer outra irregularidade como desvio de recurso, prática de ato ilegal, ilegítimo ou antieconômico que resulte em dano ao Erário, a autoridade administrativa competente possui o dever de adotar providências a fim de instaurar Tomada de Contas Especial para apurar os fatos, identificar os responsáveis e quantificar o dano, esses são os termos do art.8 o do LOTCU. Se não adotadas as providências, o próprio Tribunal instaura a Tomada de Contas Especial. 
Após, encaminham-se os autos para o TCU para fins de julgamento. É o Relator quem preside a instrução, determinando de ofício ou por provocação do órgão de instrução ou do Ministério Público, o sobrestamento do julgamento, a citação ou a audiência dos responsáveis, bem como demais providências necessárias ao saneamento dos autos, fixando prazo para o atendimento das diligências, para posteriormente submeter o feito ao Plenário ou à Câmara respectiva para decisão.

Verificada irregularidades nas contas, define-se se a responsabilidade é individual ou solidária. Em casos de débito, ordena-se a citação do responsável para apresentar defesa ou recolher a quantia devida. Se não houver débito, determina-se a audiência do responsável para apresentar justificativa. Caso a defesa seja rejeitada, o responsável é cientificado para recolher a importância. Se não atendida a citação ou audiência, a Corte de Contas o considerará revel, prosseguindo com o processo.

No julgamento de contas irregulares, fixará a responsabilidade solidária do agente público que praticou o ato e de terceiro interessado na prática do mesmo ato, quando concorreu para o cometimento do dano. Após, o Tribunal remete cópias dos autos para o Ministério Público da União ajuizar as ações civis e penais cabíveis.

A decisão definitiva é formalizada por acórdão, com publicação no Diário Oficial da União (DOU). A decisão do Tribunal, de que resulte imputação de débito ou cominação de multa, torna a dívida líquida e certa e tem eficácia de título executivo (art. 24, LOTCU). Segundo o art. 31 da LOTCU, em todas as etapas do processo de julgamento de contas, assegura-se ao responsável e ao interessado a ampla defesa.

Os recursos cabíveis em decisão proferida em processo de tomada ou prestação de contas, são recursos de reconsideração, embargos de declaração e revisão. Recurso interposto fora do prazo não é conhecido, salvo superveniência de fatos novos, nos termos do Regimento Interno (art. 32, LOTCU).

Embargos de declaração são utilizados para corrigir obscuridade, omissão ou contradição da decisão recorrida, enquanto o recurso de reconsideração possui efeito suspensivo, apreciado por quem houver proferido a decisão recorrida, pode ser formulado por escrito uma só vez, pelo responsável ou interessado, ou pelo Ministério Público junto ao Tribunal, dentro do prazo de quinze dias (art. 33, LOTCU).

0 recurso de revisão é destinado ao Plenário da Corte, sem efeito suspensivo. Deve ser interposto por escrito, uma só vez, pelo responsável, seus sucessores, ou pelo Ministério Público, dentro do prazo de cinco anos. Tem como fundamento erro de cálculo nas contas, falsidade ou insuficiência de documentos em que se tenha fundamentado a decisão recorrida e superveniência de documentos novos com eficácia sobre a prova produzida. Em decisões que derem provimento a recurso de revisão, corrige-se todo e qualquer erro ou engano apurado.

Desse modo, têm-se as definições gerais sobre o controle externo do Tribunal de Contas e sobre o processo nos termos da Lei Orgânica do Tribunal de Contas. Re- 
centemente, foi aprovado diploma legal que trouxe novas disposições à Lei de Introdução às normas do Direito Brasileiro, aplicáveis à esfera administrativa e controladora, logo, aplicáveis ao Tribunal de Contas. A investigação sobre esse recente diploma será explorado no capítulo seguinte.

\section{A Lei 13.655/2018 na Lei de Introdução às Normas do Direito Bra- sileiro (LINDB)}

O Decreto-lei no 4.657, de 4 de setembro de 1942, instituiu a Lei de Introdução às Normas do Direito Brasileiro, também conhecida como LINDB, que trata de normas autônomas e princípios aplicáveis a todos os ramos jurídicos, definindo aspectos sobre a aplicabilidade, interpretação, integração e aplicação das normas jurídicas (FARIAS; ROSENVALD; NETTO, 2018, p. 163). Apesar de ser recepcionada como lei ordinária, por sua natureza de regulamentar outras normas, de possuir a lei como tema central, costuma ser definida como um sobredireito ou um código de normas (GONÇALVES, 2018, p. 48).

Em abril de 2018, foi aprovado o Projeto de lei 7.448/2017, mais tarde sancionado como Lei 13.655/2018, que incluiu na Lei de Introdução às Normas do Direito Brasileiro novos princípios gerais que devem ser observados nas decisões originadas de órgãos públicos. Tendo em vista a aplicabilidade desse dispositivo as decisões do Tribunal de Contas, é mister realizar um estudo acerca do Projeto de Lei (PL) 7.448/2017.

\subsection{O Projeto de Lei $7.448 / 2017$}

De autoria do Senador Antônio Anastasia, com tramitação no Senado sob a identificação Projeto de Lei do Senado (PLS) 349/2015, seu texto foi elaborado inicialmente pelos professores Carlos Ari Sundfeld e Floriano de Azevedo Marques Neto, resultado de projetos de pesquisa desenvolvidos por pesquisadores da Sociedade Brasileira de Direito Público em parceria com a escola de Direito de São Paulo da Fundação Getúlio Vargas. (NETO, FREITAS, 2019, p. 7).

Inicialmente, com um total de 10 artigos, o projeto trazia em sua justificativa a necessidade de fornecer novas balizas interpretativas, processuais e de controle a serem seguidos pela administração pública, cuja mudança teria como resultado a melhoria da qualidade da atividade decisória de qualquer instância, majorando os níveis de segurança jurídica e eficiência na criação e aplicação do direito público, assim, trazendo diretrizes a serem obedecidas pelos órgãos judiciais, administrativos e de controle da administração pública.

Na esfera do Senado, ocorreu a realização de uma audiência pública no ano de 2015, com a participação de dois convidados do Poder Executivo, Sr. Arnaldo Sampaio Moraes Godoy, Procurador da Fazenda Nacional e Danilo Takasaki Carvalho, Assessor Jurídico da Secretaria Executiva do Ministério da Fazenda, ainda contou 
com a presença de um convidado dos municípios, Alexandre Schubert Curvelo, Consultor da Confederação Nacional dos Municípios.

Em análise da Comissão Permanente de Constituição, Justiça e Cidadania (CCJ) do Senado Federal, o projeto não encontrou óbice quanto a sua juridicidade, regimentalidade e técnica legislativa, a CCJ também responsável por apreciar de forma terminativa o mérito, definiu em análise que o PLS 349/2015 não incidia em qualquer inconstitucionalidade formal ou material. Desse modo, o projeto aprovado com 7 emendas, os 10 artigos originais prosseguiram para revisão da Câmara dos Deputados, com a adição de um artigo.

Em voto da Relatora, Senadora Simone Tebet, na análise do mérito afirmou que a inclusão de normas gerais de direito público na LINDB trazem uma coerência sistêmica, possibilitando a segurança jurídica, com previsibilidade de decisões e proteção das expectativas daqueles que possuem relação jurídica ou fática com a administração pública.

Simplificadamente, tramitou na Câmara dos Deputados sob o número de PL 7.448/2017. Não houve a realização de audiências e o projeto recebeu aprovação nas Comissões em caráter conclusivo. Foi interposto recurso ao Plenário pela Deputada Erika Kokay contra essa apreciação conclusiva, sob o argumento de que a tramitação de forma terminativa não permitiu os necessários debates públicos. No entanto, foi aprovado requerimento de iniciativa coletiva de retirada do recurso. Desse modo, o projeto seguiu para sanção presidencial, recebeu vetos parciais, sendo promulgada como Lei no 13.655 , em 25 de abril de 2018.

Seu período de tramitação até a aprovação foi de junho de 2015 a abril de 2017 no Senado Federal, e no período de abril de 2017 a abril de 2018 na Câmara dos Deputados. Chama a atenção, a realização de tão somente uma única audiência pública durante a tramitação no Senado, com participação limitada dos agentes, bem como a conclusão de forma terminativa da Câmara dos Deputados. Diante do impacto de tal alteração e a repercussão para a administração pública, aos órgãos de controle e Poder Judiciário, a ausência de amplo debate público mostra-se insatisfatória, especialmente na Câmara dos Deputados.

Em publicação sobre o projeto, o autor, Senador Antônio Anastasia (2015, p. 6), afirma que:

A orientação geral do projeto de lei é consolidar e melhorar as regulações e controles públicos existentes e, ao mesmo tempo, proteger as pessoas, organizações e servidores contra incertezas, riscos e custos injustos. Não é um assunto apenas para profissionais do Direito, mas para toda a sociedade. 
Naturalmente, o projeto foi objeto de diversas manifestações, a favor e contra a sanção presidencial, uma das motivações contrárias refere-se à ausência de discussão da matéria com os interessados, inclusive, os órgãos de controle, um dos principais destinatários da norma.

Quanto às suas novas disposições, a LINDB trata em seu texto acerca da responsabilização do agente público, em especial no art. 28, que é objeto de pesquisa do presente trabalho. É a redação do projeto 7.448/2017:

Art. 28. 0 agente público responderá pessoalmente por suas decisões ou opiniões técnicas em caso de dolo ou erro grosseiro.

$\S 1$ o Não se considera erro grosseiro a decisão ou opinião baseada em jurisprudência ou doutrina, ainda que não pacificadas, em orientação geral ou, ainda, em interpretação razoável, mesmo que não venha a ser posteriormente aceita por órgãos de controle ou judiciais.

$\S 2^{\circ} 0$ agente público que tiver de se defender, em qualquer esfera, por ato ou conduta praticada no exercício regular de suas competências e em observância ao interesse geral terá direito ao apoio da entidade, inclusive nas despesas com a defesa.

§ $3^{0}$ Transitada em julgado decisão que reconheça a ocorrência de dolo ou erro grosseiro, o agente público ressarcirá ao erário as despesas assumidas pela entidade em razão do apoio de que trata o $\S 2^{\circ}$ deste artigo.

0 artigo 28 foi alvo de diversos debates. 0 entendimento da Relatora na CCJ quanto ao seu conteúdo foi que a definição de erro grosseiro alcança o entendimento pacificado no Supremo Tribunal Federal (STF) sobre o tema, que a mudança de entendimentos e jurisprudência não devem alcançar os atos anteriormente praticados, especialmente quando realizada de boa-fé ou sem a presença de um erro grosseiro, conforme o $\S 1^{\circ}$ (BRASIL, 2017). Assim, a proposta exclui a responsabilização em caso de adoção de entendimento dominante à época da prática do ato.

Para Carlos Ari Sundfeld e Bruno M. Salama (2015, p. 15), o direito comporta constantes transformações de interpretação e reinterpretação pelos aplicadores e controladores. Desse modo, as novas reconstruções não poderiam atingir aqueles que emitiram opiniões passadas. Logo, as novas alterações da LINDB possibilitam a segurança jurídica do agente público.

Entretanto, em nota pública da Associação Nacional dos magistrados da Justiça do Trabalho, juntamente com entidades nacionais representativas de juízes Federais, do Ministério Público e de auditores fiscais do Trabalho apontou-se como ponto 
preocupante da proposta o subjetivismo aberto pelo projeto, a partir da inserção de valores jurídicos abstratos, entre eles o termo "erro grosseiro".

Ainda, apontaram inconstitucionalidades relativas à responsabilização dos agentes públicos, uma vez que o Projeto de Lei previa que os agentes responderiam apenas por "dolo e erro grosseiro", com parâmetros de interpretação contrários a dispositivos de controle como a Lei de improbidade, que prevê a conduta culposa para fins de responsabilização.

No mesmo sentido, em diálogo público realizado pelo Tribunal de Contas em 23 de abril de 2018, o Ministro do Superior Tribunal de Justiça (STJ) Herman Benjamin, afirmou que as disposições elencadas no artigo 28 trazem uma gradação do elemento culpa e deixa critérios abertos quanto a sua subsunção, assim, gerando insegurança jurídica quanto à classificação e aplicação do elemento culpa.

Os agentes públicos respondem por dolo ou por culpa, em qualquer grau, e não apenas por dolo e erro grosseiro. Para Ramalho e Sarquis (2018, online), o dispositivo cria permissão geral para que o administrador alegue sua própria incompetência em juízo, uma vez que erros não grosseiros não serão responsabilizados. É o mesmo entendimento da Consultoria Jurídica do Tribunal de Contas em parecer sobre o PL 7.448/2017, em que entende que o dispositivo permite uma atuação negligente, imprudente e imperita.

Em resposta ao Parecer da Consultoria Jurídica do Tribunal de Contas, defensores do PL 448/2017 alegaram que a previsão de erro grosseiro incluem situações de negligência grave, imprudência grave ou imperícia grave.

Em uma análise da conjuntura, para Palma (2019, p. 1), leis controladoras advindas dos próprios controladores demonstram um cenário de desarmonia institucional, resultando em exemplos de perturbação da segurança jurídica. Ainda, entende que as leis de controle são escritas pensando no agente ímprobo, enquanto o agente público honesto é medido pelos mesmos parâmetros do desonesto.

Por essa razão, a alteração na LINDB traz uma nova abordagem sobre o agente público e sua responsabilização. 0 conceito abstrato de erro grosseiro não é tolerante com o erro, pois imprudência e a desídia se encaixam no conceito de erro grosseiro para fins de responsabilização.

Assim, a alteração na LINDB busca garantir medidas para uma melhor estabilidade e a confiança na administração pública. Debate, ainda, que as leis dirigidas à administração pública carregam uma série de indeterminações jurídicas e que interpretá-las é tarefa indissociável da sua implementação.

Logo, a reforma busca colocar em perspectiva o modo como são empregados os conceitos jurídicos indeterminados, e que os mesmos são assim devido o alcance da sua aplicação e a impossibilidade de previsão de todas as hipóteses, portanto a 
indeterminação de alguns conceitos seriam fundamentais, inclusive pela própria característica de sobredireito da LINDB.

Em contrapartida, em Diálogo Público promovido pelo TCU em abril de 2018, a Procuradora-Geral do Ministério Público junto ao TCU, Cristina Machado, considerou que a mudança legislativa enfraquece os instrumentos de controle, as hipóteses trazidas no artigo 28 exigem um aparato de ferramentas investigativas o qual as instituições de controle não possuem. Ainda, o conceito jurídico indeterminado conduz à imprecisão do alcance do conceito.

No entanto, ainda em abril de 2018, o PL 7.448/2017 foi aprovado e sancionado como Lei 13.655/2018, que promoveu a inclusão de 10 novos artigos na LINDB. 0 dispositivo foi sancionado com veto parcial, entre eles o artigo 28. Diante das inúmeras manifestações sobre o dispositivo, é salutar abordar as motivações de seu veto parcial e os entendimentos sobre o dispositivo após a sanção.

\subsection{O veto parcial do artigo 28 e o Decreto $9.830 / 2019$}

Nos termos do artigo 66, $\S 1^{\circ}$ da Constituição Federal, os dispositivos do projeto foram vetados por contrariedade ao interesse público e inconstitucionalidade. Quanto ao artigo 28 , apenas o caput foi aprovado, enquanto os parágrafos $1^{\circ}$, $2^{\circ}$ e $3^{\circ}$ receberam o veto do Presidente da República.

0 art. $28, \S 1$ o estipulava in verbis:

Art. 28, § $1^{\text {o }}$ Não se considera erro grosseiro a decisão ou opinião baseada em jurisprudência ou doutrina, ainda que não pacificadas, em orientação geral ou, ainda, em interpretação razoável, mesmo que não venha a ser posteriormente aceita por órgãos de controle ou judiciais.

O dispositivo admitia a desconsideração de responsabilidade do agente público por decisão, opinião baseada em interpretação jurisprudencial ou doutrinária não pacificada, e, até mesmo, minoritária, qualquer que fosse. Acontece que a busca pela pacificação de entendimentos é essencial para a segurança jurídica, objetivo do projeto.

Observa-se que a hipótese admitia um único parecer jurídico contrário para desconsiderar a responsabilidade do agente. Ainda, há de se destacar que no Direito há teorias das mais diversificadas para sustentar uma tese. Desse modo, o dispositivo atribuía discricionariedade para agir com base em sua própria convicção, o que se traduzia em insegurança.

Enquanto isso, o $\S \S 2^{\circ}$ e $3^{\circ}$ estabeleciam que:

Art. $28 \S 2^{\circ} 0$ agente público que tiver de se defender, em qualquer esfera, por ato ou conduta praticada no exercício 
regular de suas competências e em observância ao interesse geral terá direito ao apoio da entidade, inclusive nas despesas com a defesa.

§ $3^{0}$ Transitada em julgado decisão que reconheça a ocorrência de dolo ou erro grosseiro, o agente público ressarcirá ao erário as despesas assumidas pela entidade em razão do apoio de que trata o $\S 2^{\circ}$ deste artigo.

Tal como era apresentado, o dispositivo permitia a utilização do erário e da máquina pública para defesa de agente que agiu com dolo, má fé e erros grosseiros, criando direito subjetivo para o agente público de obter apoio e defesa pela entidade, em qualquer esfera, decorrente de ato ou conduta praticada no exercício regular de suas competências, inclusive nas despesas com a defesa.

Assim, restava caracterizada a não exclusividade do órgão de advocacia pública na prestação, impondo a cada entidade dispêndio financeiro indevido, sem especificar as hipóteses de ocorrência desse apoio, nem o órgão responsável por esse amparo, que poderia gerar significativos ônus sobretudo para os entes subnacionais.

Após o veto parcial, o dispositivo permanece objeto de debate. Segundo o posicionamento de diversos juristas, o conceito indeterminado de erro grosseiro deixa a interpretação a juízo do julgador. Dessa forma, a redação do artigo é contraditória e inadequada com o objetivo do projeto de maximizar a segurança jurídica. (ARAÚJO, VORONOFF, FERREIRA JUNIOR, 2019, online)

Segundo os autores, o objetivo de conferir uma previsibilidade na relação com a administração pública e, consequentemente, conferir-lhe uma maior segurança jurídica, é imediatamente frustrada diante da abstração dos novos conceitos, que podem gerar margem para interpretações muito expansivas e incoerentes por parte dos órgãos de controle. Araújo, Voronoff e Ferreira Junior (2019, online) asseveram que:

Por outro lado, é necessário que as inovações legislativas funcionem como um vetor interpretativo que reforcem a necessidade da tomada de decisões uniformes, com maior deferência aos precedentes administrativos e judiciais. Também se pode cogitar de atos normativos ulteriores que densifiquem, em maior grau, o sentido de "erro grosseiro" adotado na LINDB, com vista a um equilíbrio tênue dos incentivos em jogo. A busca, aqui, é por um regime geral de responsabilização que não resulte nem em gestores públicos legalistas (e receosos), muito menos em irresponsáveis.

Para Valiati (2018, online), a indeterminação do artigo 28 do que se vem a entender como erro grosseiro, permitiu a continuidade da determinação do parâmetro de controle pelos órgãos de controle. Assim, sem esses parâmetros o controlador 
ainda possui um espaço muito amplo de atuação, que limita a inovação dos agentes públicos.

No entanto, concorda que a definição trazida contribui para valorização desse agente de boa fé. Apesar das críticas, defende que a Lei 13.655/2018 traz diversos aspectos para aprimoração da qualidade da decisão administrativa e, consequentemente, de segurança jurídica na relação com a administração pública.

Outro ponto que merece destaque é a alegação de que as novas proposições da LINDB entram em rota de colisão com o Texto Constitucional por ofensa ao art. 37, $\S 6^{\circ}$, da Constituição Federal que assim dispõe:

Art. 37, § 60 As pessoas jurídicas de direito público e as de direito privado prestadoras de serviços públicos responderão pelos danos que seus agentes, nessa qualidade, causarem a terceiros, assegurado o direito de regresso contra o responsável nos casos de dolo ou culpa.

Depreende-se do dispositivo constitucional a ausência de qualquer exigência adicional, além da demonstração do dolo ou da culpa, para se exercer o direito de regresso contra o agente público causador de um dano ao erário. Portanto, a limitação contida na proposta do art. 28 , no sentido de prever que o agente público responderá somente em caso de dolo ou erro grosseiro ofende o comando constitucional do $\S 6^{\circ}$ do art. 37, pois a Carta Magna não exige que a conduta tenha revelado erro grosseiro, bastando a culpa.

Recentemente, o Instituto Brasileiro de Direito administrativo (IBDA) realizou seminário sobre "Impactos da Lei 13.655/18 no Direito Administrativo" em junho de 2019, com elaboração de enunciados sobre a interpretação das alterações incluídas na LINDB, afirmando o seguinte:

0 art. 28 da LINDB, para os casos por ele especificados (decisões e opiniões técnicas), disciplinou o $\S 6^{\circ}$ do artigo 37 da Constituição, passando a exigir dolo ou erro grosseiro (culpa grave) também para fins da responsabilidade regressiva do agente público.

Porém, há de se ressaltar que a Lei de Introdução às normas do Direito Brasileiro ainda que norma de sobredireito, possui status de lei ordinária. Logo, a Constituição da República é hierarquicamente superior a LINDB. Desse modo, se submete aos ditames da Constituição, sendo por ela disciplinada.

Ainda, em 10 de junho de 2019, o atual presidente expediu o Decreto 9.830, que regulamentou os artigos incluídos na LINDB em razão da aprovação da Lei 
13.655/2018, com a inclusão de um artigo e 8 parágrafos sobre os critérios quanto à responsabilização do agente público em caso de dolo e erro grosseiro.

Nos termos do Decreto 9.830/2019, a responsabilidade incide em condutas omissivas e comissivas com dolo direto ou eventual, ou cometidas com erro grosseiro, no desempenho de suas funções. 0 artigo 12 e seus parágrafos do Decreto 9.830/2019 trazem os critérios para configuração do erro grosseiro e os casos de exclusão.

Estabelece ainda que o mero nexo de causalidade entre a conduta e o resultado danoso não implica responsabilização, e que o montante do dano ao erário, ainda que expressivo, não pode, por si só, ser elemento para caracterizar o erro grosseiro ou o dolo. Define que a complexidade da matéria e das atribuições exercidas pelo agente público serão consideradas em eventual responsabilização.

Estipula que a responsabilização pela opinião técnica não se estende automaticamente ao decisor que a adotou como fundamento de decidir, e só restará configurado se presentes elementos suficientes para o decisor aferir o dolo ou o erro grosseiro da opinião técnica, ou, ainda, se houver conluio entre os agentes.

Nos termos do Decreto, enquanto no exercício do poder hierárquico, o agente só responderá por culpa in vigilando quando sua omissão caracterizar erro grosseiro ou dolo. Ainda, define que os critérios estabelecidos para a configuração da responsabilização não exime o agente público de atuar de forma diligente e eficiente no cumprimento dos seus deveres constitucionais e legais.

Assim, o Decreto expedido pelo Presidente da República traz novos critérios com o objetivo de disciplinar as decisões e a interpretação de normas na administração pública. Com o veto parcial do Presidente da República ao artigo 28, a norma cujo propósito era conferir maior segurança aos administradores, deixa em aberto a delimitação do conceito de erro grosseiro e as condutas que motivam a responsabilização pessoal do agente público.

Desse modo, diante dos diversos posicionamentos a respeito do alcance e interpretação do artigo 28 da Lei de Introdução às normas do direito brasileiro, é mister traçar o entendimento utilizado após a Lei 13.655/2018. O Tribunal de Contas se apresenta como fonte capaz de delimitar esse conceito.

Dessa forma, a análise da jurisprudência da Corte de Contas poderá fornecer informações necessárias para traçar a definição do comportamento esperado do agente público para fins de segurança jurídica, tema que será explorado no item seguinte. 


\section{0 erro grosseiro em face da jurisprudência do Tribunal de Contas da}

\section{União}

Neste item, pretende-se traçar uma investigação de casos concretos, os quais derivam das decisões do Tribunal de Contas da União, para traçar o entendimento do Tribunal acerca do termo "erro grosseiro".

O TCU disponibiliza 4 bases de dados para pesquisa da jurisprudência, são elas: acórdãos, jurisprudência selecionada, publicações e súmulas.

Ao pesquisar por "Erro Grosseiro" no sistema de pesquisa jurisprudencial do Tribunal de Contas, poderá se encontrado:

Quadro 1 - resultado da busca por "Erro Grosseiro" no site do TCU:

\begin{tabular}{|r|r|}
\hline Acórdãos & 163 documento(s) encontrado(s) \\
\hline Jurisprudência Selecionada & 40 documento (s) encontrado (s) \\
\hline Publicações & 13 documento (s) encontrado (s) \\
\hline Súmulas & Nenhum documento encontrado \\
\hline Boletim do TCU (BTCU) & 6 documento (s) encontrado (s) \\
\hline
\end{tabular}

Fonte: TCU, 2019

Dessa forma, os casos escolhidos foram coletados através das ferramentas de pesquisa integrada disponíveis no próprio site do TCU, utilizando como chave da pesquisa o termo "erro grosseiro", e para refinar a pesquisa, utilizou-se o termo "artigo 28, LINDB".

A Lei 13.655/2018 é vigente desde 26 de abril de 2018, com exceção do seu artigo 29, que entrou em vigor 180 (cento e oitenta) dias após a sua publicação oficial, mas para fins deste artigo optou-se, como critério para definição e coleta de dados, pelo recorte temporal de janeiro a agosto de 2019 e pelo uso pontual de alguns julgados de 2018, cujos votos também repercutiram nos julgados de 2019.

Vale destacar que, na análise das decisões, só foi encontrada menção ao Decreto 9.830/2019, em cinco documentos, havendo divergência entre eles sobre a aplicabilidade do mesmo à esfera controladora, como se vê em Acórdão 4771/ 2019 da Primeira Câmara, Min. Relator Benjamin Zymler.

\subsection{A análise jurisprudencial}

A partir da seleção dos acórdãos do Tribunal de Contas da União, nesta pesquisa, percebe-se que a jurisprudência de contas pode ser agrupada sob três grupos, que 
congregam os temas relacionados com o termo "erro grosseiro". Para melhor compreensão do tema, este item se dividirá em: erro grosseiro como culpa grave, o erro grosseiro e o parecer técnico, e erro grosseiro e a responsabilidade financeira. Parte-se agora para sua análise.

\subsubsection{O erro grosseiro como culpa grave}

Antes de analisar a culpa dentro da jurisprudência do TCU, é mister que se faça uma abordagem dos conceitos da mesma na doutrina civilista. Assim, a culpa é elemento nuclear da responsabilidade civil (FARIAS; ROSENVALD; NETTO, 2018, p. 907). Segundo Tartuce (2017, p. 327), a responsabilidade civil pode ser dividida em duas espécies: a responsabilidade civil contratual e a responsabilidade civil extracontratual, também chamada de responsabilidade aquiliana. A primeira decorre do descumprimento de obrigações contratuais, enquanto a segunda nasce de descumprimento a preceito normativo.

Conforme o explorado no primeiro capítulo do presente trabalho, a responsabilidade decorre da infringência da lei e princípios jurídicos, do desacordo com o ordenamento jurídico. Segundo Farias, Rosenvald e Netto (2018, p. 893), a responsabilidade civil pode ser definida como "a reparação de danos injustos resultantes da violação de um dever geral de cuidado".

Segundo Cristiano Chaves de Farias e Nelson Rosenvald (2017, p. 193):

Em outras palavras, forma-se um consenso no sentido de compreender a culpa como o erro de conduta por omissão de diligência exigível no caso concreto, situação na qual o agente atua inadequadamente por descuido ou falta de habilidade, isto é, sem observar o dever de cuidado.

Segundo Venosa (2013, p. 25), não se pode afastar a noção de culpa do conceito de dever. Para melhor entendimento da culpa, esse instituto acompanha conceitos que permitem definir a sua gradação. A doutrina a divide em culpa leve, levíssima e culpa grave.

Ainda conforme o mesmo, a culpa levíssima trata da ausência de atenção extraordinária. Esse tipo de erro só pode ser percebido por pessoas dotadas de conhecimento especial para o caso, somente uma pessoa muito atenta e perita sobre um assunto seria capaz de identificá-lo (VENOSA, 2013, p. 29).

Enquanto isso, a culpa leve caracteriza-se pela infração de um dever de conduta relativa ao homem médio, a falta seria evitável com uma atenção ordinária, no sentido do homem comum ser capaz de evitar a transgressão ao dever de conduta. De outro modo, a culpa grave manifesta-se pela grosseira falta de cuidado. Trata-se de falta imprópria e essa é a forma como o TCU considera a culpa. 
O Tribunal de Contas para o exercício do poder sancionatório, majoritariamente, tem entendido como erro grosseiro aquele praticado com culpa grave. Como o definido em Acórdão 1.366/2019 - Plenário, Min. Relator Marcos Bemquerer:

Nesse sentido, para melhor conceituação de erro grosseiro, recorro à jurisprudência desta Corte de Contas, mais precisamente à precisa definição contida no Voto do Ministro Benjamin Zymler que embasou o Acórdão 2.391/2018 - Plenário: "é o que poderia ser percebido por pessoa com diligência abaixo do normal, ou seja, que seria evitado por pessoa com nível de atenção aquém do ordinário, consideradas as circunstâncias do negócio. Dito de outra forma, o erro grosseiro é o que decorreu de uma grave inobservância de um dever de cuidado, isto é, que foi praticado com culpa grave.

Desta forma, a culpa grave foi apontada como a conduta culposa mais grave. Ainda, houve a adoção do critério do administrador médio para a aferição da presença ou não de erro grosseiro. A comparação com um "gestor médio" foi realizada no Acórdão 1.695/2018-Plenário (Min. Relator: Vital do Rêgo).

Para o Tribunal, configura erro grosseiro conduta que descumpre regra constitucional, regra expressa em instrumento convenial, conduta que não observa princípios básicos da administração ou condutas que afrontam diretamente a legislação e jurisprudência do Tribunal, bem como descumprimento de normativo da entidade pelo gestor, especialmente aquele que resulta em danos materialmente relevantes.

Ainda, a decisão de gestor que desconsidera, sem a devida motivação, acórdão do TCU, pode ser tipificada como erro grosseiro para fins de responsabilização perante a Corte de Contas. Tal conduta expressa inobservância do dever de cuidado, o que configura culpa grave, motivo suficiente para a responsabilização e para a aplicação de sanção ao gestor.

Trata-se de erro grosseiro aquele manifesto, evidente e inescusável praticado com culpa grave, caracterizado por ação ou omissão com negligência extrema, imperícia ou imprudência extraordinárias. Ainda, a prática de irregularidades que eram facilmente perceptíveis se afasta do conceito de administrador médio, portanto, configurando erro grosseiro.

Apesar do padrão utilizado para aferir a grosseria ser o homem médio, vale destacar que em declaração de Voto, o Ministro Bruno Dantas declarou que o erro grosseiro não é culpa atribuível a qualquer desvio em relação à postura do homem médio, o erro grosseiro é culpa grave, situando-se entre a culpa comum e o dolo, razão pela qual não considera o critério do homem médio adequado. 
Importante também ressaltar a menção ao instituto do erro, que trata de defeito no negócio jurídico, e que pode ser conceituado como uma falsa representação da realidade. Segundo Farias, Rosenvald e Netto (2018, p. 540) "quem erra imagina existir o que não existe, ou existe de forma diferente do imaginado".

O instituto pode ser classificado como acidental ou substancial, também chamado de essencial. 0 erro acidental possui menor relevância e não gera anulabilidade do negócio jurídico, enquanto o erro substancial tem maior relevância e sua presença torna anulável o negócio jurídico (FARIAS, ROSENVALD e NETTO, 2018, p. 540).

Nos termos do artigo 138 do atual Código Civil, o erro sem nenhum tipo de qualificação quanto à sua gravidade, é aquele "que poderia ser percebido por pessoa de diligência normal, em face das circunstâncias do negócio".

Utilizando-se desse parâmetro, o erro leve foi definido como aquele que seria percebido e evitado por pessoa de diligência extraordinária, com grau de atenção acima do normal. Enquanto isso, o erro grosseiro poderia ser percebido por pessoa com diligência abaixo do normal, isto é, por pessoa com nível de atenção aquém do ordinário, consideradas as circunstâncias do negócio.

Desta forma, o erro grosseiro decorre de uma grave inobservância de um dever de cuidado, isto é, que foi praticado com culpa grave. Observa-se que, embora diversos, os institutos do erro e culpa foram apontados como sinônimos, demonstrando dissonâncias de entendimentos.

\subsubsection{O erro grosseiro e a opinião técnica}

Como visto no decorrer deste trabalho, o artigo 28 define que a responsabilidade por opinião técnica decorre de dolo e erro grosseiro. Dessa forma, será tratada nesta subseção a aplicação do instituto do erro grosseiro na elaboração de opiniões técnicas.

Para Mazza (2018, n.p.), o parecer é a manifestação enunciativa expedida por órgão técnico ou agente competente acerca de assuntos submetidos à sua apreciação. Sua finalidade é dar suporte especializado à autoridade solicitante.

Para Di Pietro (2019, p. 262), trata-se de ato enunciativo, pelo qual a administração reconhece e atesta uma situação de fato ou de direito. Essa manifestação por si só não produz consequências jurídicas. No entanto, subsidiam decisões da autoridade administrativa.

Segundo Di Pietro (2015, p. 36), o artigo 28 introduzido pela Lei 13.655/2018 2018 busca acabar com a controvérsia quanto à responsabilização dos profissionais, especialmente dos advogados públicos, pela opinião técnica ou jurídica que emitem para dar embasamento a uma decisão adotada no âmbito da Administração Pública. 
É entendimento do Tribunal de Contas que o parecerista jurídico pode ser responsabilizado solidariamente com os gestores em casos de irregularidades ou prejuízos ao erário, nos casos de erro grosseiro ou atuação culposa, desde que seu parecer seja obrigatório ou, ainda, em casos de parecer opinativo. Esse é o entendimento consolidado em diversos julgados.

Segundo a Corte de Contas, o parecerista jurídico pode ser arrolado como responsável perante o TCU baseado no art. 71, inciso II, da Constituição Federal, que define a responsabilização daqueles que derem causa a perda, extravio 'ou outra irregularidade de que resulte prejuízo ao erário'.

Ainda, a responsabilização do parecerista decorre da própria Lei 8.906, de 4 de Julho de 1994 (Estatuto da Advocacia), que dispõe em seu art. 32 que o "advogado é responsável pelos atos que, no exercício profissional, praticar com dolo ou culpa".

Assim, existindo parecer que, por dolo ou culpa, induza o administrador público à prática de irregularidade, ilegalidade ou quaisquer outros atos que firam princípios da administração pública, poderá haver a responsabilização do parecerista pelas irregularidades e prejuízos aos quais tenha dado causa.

Logo, quando o parecer jurídico for a favor de ato danoso ao erário ou com grave violação do ordenamento jurídico, configurando o nexo causal para o cometimento do ato, sujeitará o seu autor à jurisdição do Tribunal de Contas da União, no exercício da competência de fiscalizar a Administração Pública e, em consequência, às sanções por ele cominadas.

A Corte de Contas ao decidir sobre o tema de responsabilidade do parecerista e o erro grosseiro, utiliza-se do termo parecerista médio. As decisões analisadas não trazem contornos acerca desse conceito. Porém, percebe-se um entendimento no sentido de erro decorrente de grave inobservância de dever de cuidado.

A título de exemplificação, o TCU entende que o parecerista responsável pelo exame da minuta do edital possui o dever de conhecer quando os dispositivos editalícios estão aderentes às normas legais e à jurisprudência solidificada que dispõe sobre a matéria submetida a seu parecer. Assim, a não observância desse dever configura erro grosseiro.

Ainda, para fins de responsabilização, o Tribunal utiliza-se do conceito de culpa grave, assim entendida como aquele erro que pode ser percebido por pessoa com diligência abaixo do normal e que poderia ser evitado por pessoa com nível de atenção aquém do ordinário.

Em Acórdão 3530/2019 da 1르 Câmara com Min. Relator Bruno Dantas foi realizada a seguinte análise:

Relativamente à responsabilização de parecerista jurídico, esta Corte de Contas tem entendimento firmado no sentido 
de que esse profissional pode ser responsabilizado solidariamente com os gestores por irregularidades ou prejuízos ao erário, nos casos de erro grosseiro ou atuação culposa, quando seu parecer for vinculativo. (grifo nosso)

Em contrariedade ao entendimento anterior, percebe-se que ocorreu uma separação entre o instituto erro grosseiro e culpa. No entanto, o Acórdão não trouxe definição acerca do erro grosseiro. A diferenciação entre os institutos repete-se em outras decisões.

Importante ressaltar que as decisões reafirmam a responsabilidade do parecerista por conduta culposa ou dolosa, por irregularidades, ilegalidades ou prejuízos ao erário. Ainda, considera-se erro grosseiro o erro evidente e claro, bem como parecer que não observa dispositivos constitucionais, infralegais, jurisprudência consolidada dos tribunais e termos de convênio.

\subsection{O erro grosseiro e a responsabilidade financeira}

Como explorado no decorrer deste trabalho, o Tribunal de Contas da União possui competência para realizar a fiscalização financeira da administração pública. De modo a garantir que a gestão de recursos atenda a finalidade do interesse público, impõe-se ao gestor o cumprimento de normas e princípios jurídicos. Entre essas normas, inclui-se o dever de prestação de contas.

Segundo Gomes (2009, p. 32) a responsabilidade financeira pode ser definida como:

a obrigação de repor recursos públicos (imputação de débito) ou de suportar as sanções previstas em lei, no âmbito do controle exercido pelos Tribunais de Contas, em razão da violação de normas pertinentes à gestão de bens, dinheiros e valores públicos.

Dessa forma, a responsabilidade financeira está atrelada às funções de fiscalização realizadas pelo TCU, o julgamento das contas públicas e, consequentemente, em aplicações de sanções em casos de irregularidades.

0 entendimento sobre o tema encontra assento constitucional no artigo 71, inciso VIII da CF, nesses termos: "aplicar aos responsáveis, em caso de ilegalidade de despesa ou irregularidade de contas, as sanções previstas em lei, que estabelecerá, entre outras cominações, multa proporcional ao dano causado ao erário".

O TCU firmou o entendimento de que a responsabilidade financeira é uma responsabilidade de natureza subjetiva. Desse modo, segue a regra geral da responsabilidade civil. Logo, são exigidos, simultaneamente, três pressupostos para a responsabilização do gestor, são eles: o ato ilícito na gestão dos recursos públicos, conduta dolosa ou culposa e nexo de causalidade entre o dano e o comportamento do agen- 
te. Ainda, deverá ser verificada a ocorrência de excludente de culpabilidade, bem como inexigibilidade de conduta diversa ou ausência de potencial conhecimento da ilicitude.

Nos casos analisados, o erro grosseiro foi entendido como um erro invencível, uma falha rude, que foge aos limites da decência e que ultrapassa aquilo que é tido como comum ao ser humano. Ainda, o critério de culpa grave e grave inobservância do dever de cuidado também foram utilizados para explicação do termo.

Porém, em enunciado foi firmado o entendimento que o dever de indenizar os prejuízos ao erário permanece sujeito somente à comprovação de dolo ou culpa, sem qualquer gradação, inclusive para fins do direito de regresso, nos termos do artigo 37, § 6ํำ da Constituição Federal, que dispõe:

Art. 37, § 60 As pessoas jurídicas de direito público e as de direito privado prestadoras de serviços públicos responderão pelos danos que seus agentes, nessa qualidade, causarem a terceiros, assegurado o direito de regresso contra $o$ responsável nos casos de dolo ou culpa.' (grifo nosso).

Ainda, entendeu-se que, para fins de ressarcimento ao erário, a responsabilidade dos jurisdicionados perante o TCU caracteriza-se pela constatação de culpa stricto sensu, sendo desnecessário evidenciar a conduta dolosa ou a má-fé do agente público para que este seja instado a ressarcir os prejuízos que tenha causado ao erário.

Desse modo, as alterações promovidas na LINDB pela Lei 13.655/2018, em especial a inclusão da responsabilização em caso de erro grosseiro, não provocaram modificações nos requisitos necessários para a responsabilidade financeira por débito, que conserva-se vinculada à noção de culpa, sem qualquer gradação.

Segundo Voto do Acórdão 173/2019 do Plenário e Acórdão 5547/2019 da 1a Câmara, tendo o agente atuado com culpa grave, leve ou levíssima, existirá a obrigação de indenizar. Desse modo, o entendimento foi que o artigo 28 da LINDB trata exclusivamente do direito sancionador, alcançando a atividade jurisdicional do TCU, especialmente a atividade de aplicação de sanções administrativas e de correção de atos irregulares.

\section{Conclusão}

Um sistema de controle busca possibilitar o atingimento dos objetivos da administração pública no desempenho da sua atividade e evitar os desvios e falhas na condução da máquina administrativa. 0 desenvolvimento do presente estudo possibilitou contornar a competência constitucional atribuída ao Tribunal de Contas para a realização do controle externo e o processo para a avaliação de gestão e de responsabilização de pessoas. 
Através da análise de doutrina e legislação vigente, observa-se que a atividade da Corte de Contas direciona-se ao objetivo de auxiliar o aperfeiçoamento da administração pública. Além disso, também permitiu uma pesquisa para obtenção de dados mais consistentes acerca do processo de aprovação do PL 7.448/2017, sancionado como Lei 13.655/2018.

Apesar da proposta de melhoria da qualidade da atividade decisória e, consequentemente, majoração dos níveis de segurança jurídica e eficiência na criação e aplicação do direito público, observa-se que o artigo 28 demonstra um sentido inverso ao proposto, com a inserção de conceito jurídico aberto, reflexo do subjetivismo do Projeto de Lei 7.448/2017.

Percebe-se que apesar das alterações na LINDB possuírem impacto para órgãos de controle da administração pública, para o Poder Judiciário e administrados, a tramitação do Projeto não permitiu os necessários debates públicos, inclusive, como comprovado pela não participação de órgãos de controle e judiciário em única audiência pública realizada durante a tramitação no Senado.

Diversos dispositivos de controle abordados durante este trabalho demonstraram a exigência para responsabilização do agente público apenas de dolo ou culpa, em qualquer grau, e a alteração na LINDB traz novo critério de gradação para responsabilidade, inclusive, de modo diverso do estabelecido em texto Constitucional.

Esta pesquisa a partir dos contornos delineados na jurisprudência do TCU, procurou investigar a conceituação do erro grosseiro para a Corte de Contas após as alterações da LINDB. Percebe-se que, majoritariamente, o Tribunal utiliza-se do conceito de culpa grave para conceituação do erro grosseiro, desse modo, admitindo uma gradação do instituto.

Ainda, critérios como o homem médio foram utilizados para conceituação do erro grosseiro. Apesar disso, o TCU apresentou decisões que não consideraram o homem médio como critério adequado, e, ainda, mistura os institutos distintos de culpa e erro quando da gradação do instituto, demonstrando dissonâncias na jurisprudência da Corte, que prejudicam a conceituação precisa do erro grosseiro.

Quanto a aplicação do erro grosseiro nas análises do parecer técnico, observa-se que o Tribunal também utiliza do conceito de culpa grave, assim entendida como aquele erro que poderia ser evitado por pessoa com nível de atenção aquém do ordinário.

No entanto, em alguns acórdãos analisados, segundo a Corte de Contas, poderá haver a responsabilização do parecerista existindo parecer que, por dolo ou culpa, induza o administrador público à prática de irregularidade, ilegalidade ou quaisquer outros atos que firam princípios da administração pública. Observa-se que o elemento culpa é conceituado de forma genérica, não ficando claro a aplicação da sua gradação para fins de conceituação do erro grosseiro. 
Ainda, cabe também considerar acórdãos que decidiram a responsabilização do parecerista com fundamentos na Lei 8.906 de 4 de Julho de 1994 (Estatuto da Advocacia), que exige para fins de responsabilização atos praticados com dolo ou culpa. Novamente, sem especificar quanto à gradação do elemento e, portanto, em contrariedade ao definido na LINDB.

Outra controvérsia identificada foi a hipótese de responsabilização solidária do parecerista jurídico com os gestores em casos de irregularidades ou prejuízos ao erário, nos casos de erro grosseiro ou atuação culposa. Percebe-se que apesar de alguns entendimentos do erro grosseiro como modalidade mais grave da culpa, houve uma diferenciação desses institutos, gerando controvérsia quanto ao entendimento do TCU.

Por fim, resta a análise da aplicação das alterações da LINDB em casos de responsabilidade financeira, ou seja, casos de indenização de prejuízos ao erário. Apesar da retomada de critérios como falha que ultrapassa aquilo que é tido como comum ao ser humano, culpa grave e grave inobservância do dever de cuidado, o TCU entende que a responsabilidade financeira possui natureza subjetiva, seguindo a regra geral da responsabilidade civil.

Logo, o TCU entende que para a análise da responsabilidade financeira, exige-se somente a comprovação do ato ilícito na gestão dos recursos públicos, conduta dolosa ou culposa, sem qualquer gradação, e nexo de causalidade entre o dano e o comportamento do agente. Inclusive para fins de regresso, nos termos definidos da Constituição Federal.

Desta forma, verifica-se que, apesar do entendimento majoritário sobre erro grosseiro enquanto culpa grave, o Tribunal de Contas da União ainda apresenta dissonâncias de entendimento que dificultam a conceituação do instituto. No entanto, tal fato pode ser atribuído à recente mudança legislativa da LINDB outrora citada neste trabalho.

Desse modo, é pertinente apontar a importância de uma uniformização da Jurisprudência quando aplicada em relação a máquina administrativa, para, assim, buscar garantir a segurança jurídica enquanto Estado Democrático de Direito, em especial, sob aspecto de legalidade ao qual se submete durante a sua atuação.

Ainda, vislumbra-se a importância de se analisar a aplicação do instituto do erro grosseiro dentro da jurisprudência dos Tribunais de Contas Estaduais em face da jurisprudência do Tribunal de Contas da União e da Lei de Introdução das Normas Brasileiras, quanto também da necessidade de uma uniformização de entendimentos, o que poderá ser desdobramento da presente pesquisa. 


\section{Referências bibliográficas}

ANAMATRA, AJUFE, ANPT, ANPR, CONAMP, SINAIT. Ofício ANAMATRA $\mathrm{n}$ o 219/2018. Brasília, 2018. Disponível em: <https://www.conamp.org.br/images/notas_publicas/2018/Ofi\%CC\%81cio_veto_PL\%207 448_2017.pdf>. Acesso em: 27 ago 2019

ANASTASIA, Antônio Augusto Junho. Apresentação. In: PEREIRA, Flávio Henrique Unes (coord.). Segurança jurídica e qualidade das decisões públicas: Desafios de uma sociedade democrática: Estudos sobre o Projeto de Lei no 349/2015, que inclui, na Lei de Introdução às Normas do Direito Brasileiro, disposições para aumentar a segurança jurídica e a eficiência na aplicação do direito público. Senado Federal: Brasília, 2015. Disponível em: $<$ http://anastasia.com.br/seguranca-juridica-e-qualidade-das-decisoespublicas/>. Acesso em: 29 ago 2019.

ARAÚJO, Thiago C.; VORONOFF, Alice; FERREIRA JUNIOR, Fernando. Delimitação do conceito de 'erro grosseiro' na jurisprudência do TCU. Disponível em: $<$ https://www.jota.info/paywall?redirect_to=//www.jota.info/opiniao-eanalise/colunas/tribuna-da-advocacia-publica/delimitacao-do-conceitode-erro-grosseiro-na-jurisprudencia-do-tcu-15042019>. Acesso em: 26 jun 2019.

BRASIL. Constituição da República Federativa do Brasil, de 5 de outubro de 1988 (atualizada até a Emenda Constitucional 101, de 3.7.2019). Disponível em: <http://www.planalto.gov.br/ccivil_03/Constituicao/Constituicao.htm>. Acesso em: 4 set 2019.

. Decreto-Lei no 4.657, de 04 de setembro de 1942. Lei de Introdução às normas do Direito Brasileiro. Disponível em: < http://www.planalto.gov.br/ccivil_03/decreto-lei/Del4657compilado.htm>. Acesso em: 28 ago 2019.

. Lei 8.112, de 11 de dezembro de 1990. Dispõe sobre o regime jurídico dos servidores públicos civis da União, das autarquias e das fundações públicas federais. Brasília. Disponível em: <http://www.planalto.gov.br/ccivil_03/leis/18112cons.htm> Acesso em: 28 ago 2019.

. Lei no 8.443, de 16 de julho de 1992. Dispõe sobre a Lei Orgânica do Tribunal de Contas da União e dá outras providências. Brasília. Disponível em: <http://www.planalto.gov.br/ccivil 03/leis/L8443.htm>. Acesso em: 4 set 2019.

. Lei no 8.906, de 4 de Julho de 1994. Dispõe sobre o Estatuto da Advocacia e a Ordem dos Advogados do Brasil (OAB). Brasília. Disponível em: <http://www.planalto.gov.br/ccivil_03/Leis/L8906.htm>. Acesso em: 4 set 2019. 
Senado Federal. Comissão de Constituição, Justiça e Cidadania. Parecer $\mathrm{n}^{0}$ 22, de 29 de Março de 2017, , sobre o processo Projeto de Lei do Senado ${ }^{\circ}$ 349, de 2015, do Senador Antonio Anastasia, que Inclui, na Lei de Introdução às Normas do Direito Brasileiro (Decreto-lei n. 4.657, de 1942), disposições sobre segurança jurídica e eficiência na criação e aplicação do direito público. Relatora: Senadora Simone Tebet Disponível em: <https://www25.senado.leg.br/web/atividade/materias/-/materia/121664>. Acesso em: 28 ago 2019.

. Tribunal de Contas da União (TCU). Acórdão 173/2019. Relator: Min. Benjamin Zymler. Diário Oficial da União. Brasília, 06 de fevereiro de 2019. Disponível em: <https://pesquisa.apps.tcu.gov.br/\#/redireciona/acordaocompleto/\%22ACORDAO-COMPLET0-2342763\%22>. Acesso em: 3 set 2019

Acórdão 1.366/2019 . Relator: Min. Marcos Bemquerer. Diário Oficial da União. Brasília, 12 de junho de 2019. Disponível em: <https://pesquisa.apps.tcu.gov.br/\#/redireciona/acordao-completo/\%22ACORDAO-COMPLETO-2310775\%22>. Acesso em: 3 set 2019.

Acórdão 1.695/2018. Relator: Min. Vital do Rêgo. Diário Oficial da União. Brasília, 25 de julho de 2018. Disponível em: <https://pesquisa.apps.tcu.gov.br/\#/redireciona/acordao-completo/\%22ACORDAO-COMPLETO-2303694\%22>. Acesso em: 3 set 2019.

Acórdão 2.391/2018. Relator: Min. Benjamin Zymler. Diário Oficial da União. Brasília, 17 de outubro de 2018. Disponível em: <https://pesquisa.apps.tcu.gov.br/\#/redireciona/acordao-completo/\%22ACORDAO-COMPLETO-2287602\%22>. Acesso em: 3 set 2019.

Acórdão 3.530/2019. Relator: Min. Bruno Dantas. Diário Oficial da União. Brasília, 30 de abril de 2019. Disponível em: < https://pesquisa.apps.tcu.gov.br/\#/redireciona/acordao-completo/\%22ACORDAO-COMPLETO-2349042\%22>.Acesso em: 3 set 2019.

Acórdão 4.771 de 2019. Relator: Min. Benjamin Zymler. Diário Oficial da União. Brasília, 25 de junho de 2019. Disponível em: <https://pesquisa.apps.tcu.gov.br/\#/redireciona/acordao-completo/\%22ACORDAO-COMPLETO-2347293\%22>. Acesso em: 3 set 2019.

Acórdão 5.547/2019. Relator: Min. Benjamin Zymler. Diário Oficial da União. Brasília, 09 de julho de 2019. Disponível em: <https://pesquisa.apps.tcu.gov.br/\#/redireciona/acordao-completo/\%22ACORDAO-COMPLETO-2359192\%22>. Acesso em: 3 set 2019.

Diálogo público: Discussão do Projeto de Lei 7.448/2017. Palestrantes: Ministro Raimundo Carreiro et al. Brasília : TCU, Secretaria-Geral da Presidência (Segepres), 2018. Disponível em: <https://por- 
tal.tcu.gov.br/data/fi-

les/CD/E3/51/19/E151F6107AD96FE6F18818A8/Discussao projeto lei 7.448 2017.pdf>. Acesso em 30 jul 2020.

. Instituto Serzedello Corrêa. Responsabilização de Agentes segundo a jurisprudência do TCU- Uma abordagem a partir de Licitações e Contratos. Brasília, 2013.

CARVALHO FILHO, José dos Santos. Manual de Direito Administrativo. 24a.ed, revista, ampliada e atualizada. Rio de Janeiro: Editora Lumen Juris, 2011.

CAVALIERI FILHO, Sergio. Programa de responsabilidade civil. - 10.ed. - São Paulo: Atlas, 2012.

DI PIETRO, Maria Sylvia Zanella. Direito administrativo. 32. ed. Rio de Janeiro: Forense, 2019.

DI PIETRO, Maria Sylvia Zanella. Artigo 27. In: PEREIRA, Flávio Henrique Unes (coord.). Segurança jurídica e qualidade das decisões públicas: desafios de uma sociedade democrática. Brasília: Senado, 2015.

FARIAS, Cristiano Chaves de; ROSENVALD, Nelson. Curso de Direito Civil. Responsabilidade Civil. 4. ed. Salvador: Editora Juspodvim, 2017. Vol. 3.

FARIAS, Cristiano Chaves de; ROSENVALD, Nelson; NETTO, Felipe Braga. Manual de Direito Civil. 3. ed. Salvador: Editora Juspodivm, 2018. Vol. único.

GOMES, Emerson Cesar da Silva. Responsabilidade financeira: uma teoria sobre a responsabilidade no âmbito dos tribunais de contas. 2009. 379 f. Dissertação (Mestrado) - Curso de Direito, Universidade de São Paulo, São Paulo, 2009. Disponível em: <https://teses.usp.br/teses/disponiveis/2/2133/tde-26092011-093734/pt-br.php>. Acesso em: 30 out 2019.

GONÇALVES, Carlos Roberto. Direito civil brasileiro: Parte geral. 16. ed. São Paulo: Saraiva Educação, 2018. Vol. 1.

INSTITUTO BRASILEIRO DE DIREITO ADMINISTRATIVO (IBDA). Enunciados relativos à interpretação da Lei de Introdução às Normas do Direito Brasileiro LINDB e seus impactos no Direito Administrativo. Seminário Impactos da Lei 13.655/2018 no Direito Administrativo Brasileiro. Tiradentes/MG, 2019.

JUSTEN FILHO, Marçal. Curso de direito administrativo. 4. ed. rev. e atual. São Paulo: Saraiva, 2009.

LIMA, Luiz Henrique. Controle externo: teoria e jurisprudência para os tribunais de contas. 7. ed. rev. e atual. Rio de Janeiro: Forense; São Paulo : Método, 2018. Arquivo digital.

MARINELA, Fernanda. Direito administrativo. 4. ed. Niterói: Impetus, 2010. 
MARQUES NETO, Floriano de Azevedo; FREITAS, Rafael Véras de. Comentários à Lei no 13.655/2018 (Lei da Segurança para a Inovação Pública). Belo Horizonte: Fórum, 2019.

MAZZA, Alexandre. Manual de direito administrativo. 8. ed. São Paulo: Saraiva Educação, 2018. Arquivo digital, não paginado.

MEIRELLES, Hely Lopes. Direito administrativo brasileiro. 42. ed. atual. até a Emenda Constitucional 90, de 15.9.2015. São Paulo: Malheiros, 2016

RAMALHO, Dimas; SARQUIS, Alexandre Manir Figueiredo. PL 7448/2017 - Condescendência no atacado. 2018. Disponível em: <https://www.jota.info/paywall?redirect_to=//www.jota.info/opiniao-e-analise/artigos/pl-7448-201 7-condescendencia-no-atacado-17042018>. Acesso em: 02 set 2019.

SUNDFELD, Carlos Ari; SALAMA, Bruno Meyerhof. Chegou a hora de mudar a velha Lei de Introdução. In: PEREIRA, Flávio Henrique Unes (coord.). Segurança jurídica e qualidade das decisões públicas. Senado Federal: Brasília, 2015. Disponível em: <http://anastasia.com.br/seguranca-juridica-e-qualidadedas-decisoes-publicas/>. Acesso em: 29 ago 2019.

TARTUCE, Flávio. Manual de direito civil: volume único. 7. ed. rev., atual. e ampl. Rio de Janeiro: Forense; São Paulo: Método, 2017.

VALIATI, Thiago Priess. 0 impacto da Nova Lei de Introdução (L.13.655/18) na aplicação da LIA: o desestímulo ao direito administrativo do medo. 2018. Disponível em: <http://www.direitodoestado.com.br/colunistas/thiagopriess-valiati/o-impacto-da-nova-lei-de-introducao-l-13655-18-na-aplicacao-da-lia-o-desestimulo-ao-direito-administrativo-do-medo>. Acesso em: 02 set 2019.

VENOSA, Sílvio de Salvo. Direito Civil: Responsabilidade civil. 13. ed. São Paulo: Atlas, 2013. Coleção direito civil; Vol. 4. 